\title{
Sánchez Gudiño, Hugo y Farrera Bravo, Gonzalo (coords.), Pasado, presente y futuro de los partidos políticos en México, México, UNAM-Miguel Ángel Porrúa, 2011, 366 pp.
}

El libro Pasado, presente y futuro de los partidos políticos en México, coordinado por Hugo Sánchez Gudiño y Gonzalo Farrera Bravo, publicado por la UNAM y la editorial Miguel Ángel Porrúa en 2011, se integra por 366 páginas. Se trata de un libro, como lo menciona su introducción, que es fruto de los trabajos del Coloquio de Derecho Electoral. Pasado, Presente y Futuro de los Partidos Políticos en México, realizado a finales de 2009, cuya organización recayó en la División de Estudios de Posgrado e Investigación de la Facultad de Estudios Superiores Aragón y la Coordinación del Programa de Posgrado en Derecho de la UNAM.

Dicho libro refleja el esfuerzo conjunto de autores, una autora y de varias instituciones porque se cuente con un texto que contenga los principales temas relativos a los partidos políticos, partiendo desde su perspectiva histórica, social, filosófica, constitucional e internacional, abordando los temas y casos de actualidad, el creciente descrédito de la ciudadanía hacia éstos y la clase política o el periodo de reajuste por el que atraviesan, y las recientes tendencias.

Este libro surge en un contexto bibliográfico escaso, en donde en nuestro país sólo existen aproximadamente no más de 10 obras; específicamente en cinco de éstas se aborda un sólo tema con relación 
a éstos; por ejemplo, sólo su financiamiento; su origen y evolución; su relación con el Estado; su vínculo con la educación superior, y los partidos políticos y grupos de presión, y en cinco obras más se aborda en general el tema de los partidos políticos en México. El primer libro data de 1954; tres son de los años 70; dos de los años 80; tres de los 90 (1992, 1994 y 1999), y el que era más reciente es de 2003, ahora y después de ocho años, ya podemos contar con uno más de 2011: Pasado, presente y futuro de los partidos políticos en México, México, UNAM y Miguel Ángel Porrúa, 2011, 366 pp.

De su lectura completa, se pueden compartir muchas ideas pero también diferir de otras. Se trata de una revisión objetiva y crítica de los partidos políticos en México, pero también contiene algunas referencias a éstos respecto de los que existen en otros países. Éste puede ser considerado como una guía muy útil, muy crítica y muy plural para los(as) estudiantes, militantes, adherentes y simpatizantes de algún partido político, y público en general, para acercarse a la problemática y realidad de los partidos, ya que contiene significativos artículos sobre los partidos y los medios de comunicación; la creación de la sociedad de la información en cafés, bares, iglesias, jardines, escuelas, academias, conventos, restaurantes, institutos, etcétera, lugares que dan origen a los partidos políticos modernos en el siglo XVIII con la Revolución Francesa de 1789.

De igual forma, el contenido de este libro aborda los distintos sistemas de partidos, en donde el nuestro, el mexicano, surge en los años 70 , época de lo que algunos investigadores hemos identificado como el inicio de la transición a la democracia o, mejor dicho, de la transición jurídica y que, desde 1988, es un sistema tripartita (PAN, PRI y $\mathrm{PRD}$ ) con pequeños partidos de acompañamiento (PT, PVEM, Panal y Movimiento Ciudadano).

Otro tema que aborda el libro es la necesaria y urgente participación ciudadana y la corrupción política y administrativa, motivo por el cual se pide en sus líneas que los partidos políticos depuren de sus filas a integrantes coludidos(as) con el crimen organizado. También comprende la historia jurídica, pasada y contemporánea de los partidos en México, entendida como su sujeción al Estado de Derecho; que se respete el principio constitucional de legalidad electoral por parte de la autoridad y los(as) ciudadanos(as); que se realice la búsqueda de su transparencia, rendición de cuentas, equidad en el financiamiento, comunicación política, espacio público, entre otros, todo ello a través 
de reformas, sin olvidar que también son necesarias modificaciones a sus documentos básicos o regulación interna como son el estatuto, declaración de principios y programa de acción.

Este libro aborda el desarrollo amplio, completo y minucioso del derecho penal electoral, sus orígenes, generalidades y delitos, en donde concurren diversas autoridades, así como el tema del acceso a la justicia de manera interdisciplinaria y la propuesta de incluir que los(as) ciudadanos(as) y organizaciones con fines electorales tengan el derecho de presentar acciones de inconstitucionalidad; trata también el tema del control de los procesos electorales desde el ámbito del sistema europeo e interamericano; la representación política; la participación de la mujer en éstos, y los escenarios políticos del proceso electoral de 2012 haciendo un pronóstico basado en los resultados de las elecciones intermedias de 2009.

De la lectura de este libro se puede observar que las colaboraciones en él contenidas fueron elaboradas por una distinguida y varios distinguidos universitarios, ya que agrupa la problemática planteada en la actualidad desde el enfoque de la especialidad jurídica de cada uno de los autores y autora. También se advierte que existen problemas que llevan a replantear la viabilidad de los sistemas democráticos, para lo cual se condensan, de una manera ágil e inteligente, datos actuales sobre la democracia y se realizan preguntas con respuestas interesantes; por ejemplo, el 62\% está de acuerdo con que la democracia tiene problemas, pero es el mejor sistema de gobierno a pesar de estar desacreditado; respecto a la pregunta cuán democrático es su país, México obtuvo la calificación de 6.0 en un contexto en donde en todas partes del mundo la democracia está en crisis, pero no con en el mismo grado, y en donde la mayoría coincide en que se tiene un tipo de ciudadano(a) escéptico(a) (o pasivo(a)) que no confía en el acomodo institucional, que carece de interés, que ni siquiera va a votar, que no está informado(a), que tiene una opinión pobre de los partidos políticos, los(as) legisladores(as) y la administración de justicia, que está indeciso(a), y en donde funcionan los autoritarismos electorales. En palabras de un autor de esta interesante obra, lo democrático es contrario a lo autocrático, entendido el primero como una especie de gobierno colectivo y, el segundo, como el gobierno de una sola persona, pero esta delimitación para él no es tan cierta, porque paradójicamente la democracia puede ser autocrática y sustentarse en una simulación. En este contexto, se concluye en este libro que, en gran parte de los sis- 
temas democráticos, los partidos políticos carecen de confianza, son mal vistos por la ciudadanía e, incluso, en el campo académico existe una corriente, como se afirma en este libro, de que los mismos están en declive y en decadencia. A ese respecto, se rompe el equilibrio del sistema de partidos, lo que puede implicar el surgimiento de un sistema con bloques de partidos, las llamadas coaliciones que, incluso, le llaman competencia bipolar.

En este sentido, se comenta en esta obra que la existencia de partidos tiene ventajas si funcionan bien, por ejemplo, éstos simplifican la manera de elegir, reclutan a líderes, educan a los ciudadanos(as), los movilizan para participar, colocan a sus militantes en el gobierno, estabilizan el ejercicio del gobierno, entre otros, pero se coincide que en el caso de México hoy en día todos estos puntos son muy cuestionables, es decir, en su mayoría no se llevan a cabo. Se afirma que pareciera que la democracia siempre está potencialmente en peligro y, para nuestro país, se pretende que con la reforma política se dé más poder a la ciudadanía y disminuirá la ineficiente partidocracia. No obstante, se comenta que dicha reforma representa una simple simulación a la solución del problema estructural de fondo, porque a pesar de ser abundante nuestra legislación sigue siendo incompleta. Por ello, y a pesar de la reforma de 2007-2008, coinciden los autores que lo que se requiere es la reingeniería de las instituciones del Estado y su reforzamiento; sin embargo, en el Congreso, las fuerzas políticas ahí representadas no tienen voluntad de negociar o no quieren acuerdos para actualizar la legislación y tampoco quieren actualizar a las instituciones. Coinciden también que el problema no es la cantidad de recursos, sino la calidad del gasto que hacen los partidos políticos. En palabras de autores de esta obra, éstos no buscan el contacto directo con la sociedad, no difunden la pluralidad de ideas, no presentan plataformas ideológicas, no fomentan la crítica, y no tienen una sana política de austeridad, entre otros. No garantizan el derecho a la información de los(as) ciudadanos(as). Y, lo más absurdo, que a pesar de ser entidades de interés público o cuasi organismos del Estado, con presupuesto, no están obligados expresamente en la Ley de Transparencia.

Por otra parte, una autora de la obra observa que a pesar de garantizar en el ámbito jurídico la participación política de la mujer para que la postulación de candidatos de ambos sexos sea equilibrada con las denominadas "acciones afirmativas" o "acciones positivas", y se asuma 
la responsabilidad de generar cambios de prioridades en las instituciones y de la cultura política para que también cambie la sociedad, se renuncia hoy en día a ello.

Lo urgente en esta materia es, como se concluye en una de las aportaciones de este libro, que los partidos políticos en uso de su autonomía respeten al Estado, lo cual implica que sea con una fuerte regulación de éstos; lo mismo sucede con los medios de comunicación, siendo necesaria su regulación y que opere un modelo de comunicación ciudadana; también fortalecer los mecanismos de fiscalización; que exista mayor profesionalismo; que el IFE, de manera más objetiva y exhaustiva, realice el monitoreo de los mensajes de propaganda electoral, que verifique que los partidos cumplan con sus fines constitucionales, $y$ que participe la sociedad, entre otros.

Por todo lo anterior, este libro es un importante material de apoyo para académicos(as), estudiantes, servidores(as) públicos(as), miembros de la sociedad civil y en general para todas las personas interesadas en el tema. Seguramente el esfuerzo de quienes lo coordinaron, de los que participaron en su elaboración, así como el de las instituciones que lo publicaron, quedará recompensado al verlo convertido en una obra de consulta primordial de los(as) interesados(as) en el tema, entre éstos, principalmente los militantes, adherentes y simpatizantes de algún partido político.

\section{Susana Thalía Pedroza de la Llave} Investigadora en el Instituto de Investigaciones Jurídicas de la UNAM 